\title{
Proposal of Yaniaceae fam. nov. and Yania flava sp. nov. and emended description of the genus Yania
}

Correspondence

Wen-Jun Li

wjli@ynu.edu.cn

Cheng-Lin Jiang

lihxu@ynu.edu.cn

\author{
Wen-Jun Li, ${ }^{1}$ Peter Schumann, ${ }^{2}$ Yu-Oin Zhang, ${ }^{1} \dagger$ Ping $\mathrm{Xu},{ }^{1}$ \\ Guo-Zhong Chen, ${ }^{1}$ Li-Hua Xu, ${ }^{1}$ Erko Stackebrandt ${ }^{2}$ \\ and Cheng-Lin Jiang ${ }^{1}$
}

\begin{abstract}
${ }^{1}$ The Key Laboratory for Microbial Resources of Ministry of Education, Yunnan Institute of Microbiology and Laboratory for Conservation and Utilization of Bio-Resources, Yunnan University, Kunming, Yunnan, 650091, P. R. China

${ }^{2}$ DSMZ-Deutsche Sammlung von Mikroorganismen und Zellkulturen GmbH, Mascheroder Weg 1b, D-38124 Braunschweig, Germany
\end{abstract}

\begin{abstract}
A coccoid actinobacterium strain (designated YIM $70178^{\top}$ ) was isolated from a soil sample collected in Qinghai Province, China. The isolate grew well with an optimum salt concentration of $10-15 \%(\mathrm{KCl}, \mathrm{w} / \mathrm{v})$ but scarcely or not at all without salt. The cell-wall peptidoglycan type was $\mathrm{A} 4 \alpha$, L-Lys-Gly-L-Glu. The major polar lipids were diphosphatidylglycerol, phosphatidylglycerol, an unknown phospholipid and an unknown glycolipid. The predominant menaquinones were MK-8 and MK-9. The major fatty acid was anteiso- $C_{15: 0}$. The DNA G+C content was 57.9 mol\%. Phylogenetic analysis based on 16S rRNA gene sequences showed that strain YIM $70178^{\top}$ was most closely related to the type strain of Yania halotolerans. DNA-DNA hybridization and comparison of physiological and chemotaxonomic characteristics demonstrated that strain YIM $70178^{\top}$ was different from Yania halotolerans. The name Yania flava sp. nov. is proposed, with strain YIM $70178^{\top}$ (=DSM $16377^{\top}=$ KCTC $19047^{\top}$ ) as the type strain. Based on the phenotypic characteristics and phylogenetic position, as determined by $16 \mathrm{~S}$ rRNA gene analysis and 16S rRNA signature nucleotide data, the genus description of Yania is therefore emended and strains YIM $70085^{\top}$ and YIM $70178^{\top}$ represent a novel family of the suborder Micrococcineae, for which the name Yaniaceae fam. nov. is proposed.
\end{abstract}

The suborder Micrococcineae was proposed by Stackebrandt et al. (1997) based on their newly established hierarchic classification system for actinomycetes, the class Actinobacteria (high DNA G + C Gram-positive bacteria) and contained the families Micrococcaceae, Brevibacteriaceae, Cellulomonadaceae, Promicromonosporaceae, Dermatophilaceae, Dermabacteraceae, Intrasporangiaceae, Jonesiaceae and Microbacteriaceae. With the subsequent addition of

Published online ahead of print on 13 May 2005 as DOI 10.1099/ ijs.0.63594-0.

tPresent address: Institute of Medicinal Biotechnology, Chinese Academy of Medical Sciences \& Peking Union Medical College, Beijing 100050, P. R. China.

The GenBank/EMBL/DDBJ accession number for the 16S rRNA gene sequence of Yania flava YIM $70178^{\top}$ is AY684123.

A detailed phylogenetic tree based on 16S rRNA gene sequences displaying the position of Yania flava YIM 70178' ${ }^{\top}$, Yania halotolerans YIM $70085^{\top}$ and related taxa in the suborder Micrococcineae is available as supplementary material in IJSEM Online. novel taxa into the suborder Micrococcineae, the phylogenetic coherence of some families was disrupted, leading to the proposal of another five families, Bogoriellaceae, Dermacoccaceae, Rarobacteraceae, Sanguibacteraceae (Stackebrandt \& Schumann, 2000) and 'Beutenbergiaceae' (Garrity \& Holt, 2001).

The genus Yania has been described recently and placed within the suborder Micrococcineae (W.-J. Li et al., 2004a). Although the described isolate exhibited low $(<94 \cdot 3 \%)$ similarity to its phylogenetic neighbours and its $16 \mathrm{~S}$ rRNA gene signature nucleotides differed significantly from those of members of the suborder Micrococcineae, a new family was not proposed because we were aware that a description based on a single isolate would probably not reflect the phenotypic diversity of the taxon.

Recently, another Gram-positive actinobacterium (designated YIM $70178^{\mathrm{T}}$ ) of the genus Yania was isolated from a hypersaline habitat in Qinghai Province, China. The 16S rRNA gene sequence of strain YIM $70178^{\mathrm{T}}$ was closest to 
Yania halotolerans YIM $70085^{\mathrm{T}}$, the type species of the genus Yania. Subsequent DNA-DNA hybridization and comparison of physiological and chemotaxonomic data demonstrated that strain YIM $70178^{\mathrm{T}}$ was different from Yania halotolerans YIM $70085^{\mathrm{T}}$. The name Yania flava sp. nov. is proposed for this novel strain. In addition, the family Yaniaceae fam. nov. is proposed based on its distinct phylogenetic lineage and 16S rRNA gene sequence signature nucleotides within the suborder Micrococcineae.

Strain YIM $70178^{\mathrm{T}}$ was isolated by the dilution plating method from a saline soil sample from Qinghai Province, in north-west China. The medium used for selective isolation was SGA agar (Al-Tai \& Ruan, 1994) (pH 7•2) supplemented with $20 \%(\mathrm{w} / \mathrm{v}) \mathrm{KCl}$. The culture was incubated at $28{ }^{\circ} \mathrm{C}$ for about 2 weeks. The strain was maintained on ISP5 agar slants containing $10 \%(\mathrm{w} / \mathrm{v}) \mathrm{KCl}$ at $4{ }^{\circ} \mathrm{C}$ and in glycerol suspensions $(20 \% \mathrm{v} / \mathrm{v})$ at $-20{ }^{\circ} \mathrm{C}$. Biomass for chemical and molecular systematic studies was obtained by cultivation in shaken flasks (about 150 r.p.m.) of modified ISP5 medium $(\mathrm{KCl} 10 \% \mathrm{w} / \mathrm{v}, \mathrm{pH} 7 \cdot 0)$ broth at $28{ }^{\circ} \mathrm{C}$ for 1 week.

Cell morphology and metabolic properties were studied as described previously (Chen et al., 2004; W.-J. Li et al., 2004a, b). The colour of colonies was determined with colour chips from the ISCC-NBS colour charts standard samples no. 2106 (Kelly, 1964). In addition, acid production from carbohydrates was examined by a slightly modified method after Gordon et al. (1974).

Morphological observation of $24-48 \mathrm{~h}$ cultures of strain YIM $70178^{\mathrm{T}}$ grown on ISP5 medium supplemented with $10 \% \mathrm{KCl}(\mathrm{w} / \mathrm{v})$ revealed that the cells were similar to those of strain YIM $70085^{\mathrm{T}}$, i.e. non-motile cocci, $0 \cdot 4-0 \cdot 8 \mu \mathrm{m}$ in diameter. The colony characteristics were also similar to those of strain YIM $70085^{\mathrm{T}}$; light yellow, circular, lubricous and opaque. Some physiological and biochemical characteristics of strain YIM $70178^{\mathrm{T}}$ are presented in Table 1 .

Chemotaxonomic properties, including peptidoglycan type, polar lipids, menaquinones and whole-cell fatty acid pattern, were analysed as described previously (Chen et al., 2004; W. -J. Li et al., 2004a, b). The DNA G+C content was determined by reverse-phase HPLC according to Mesbah et al. (1989). The cellular fatty acid profile contained anteiso- $\mathrm{C}_{15: 0}(58 \cdot 20 \%)$, iso- $\mathrm{C}_{14: 0}(12 \cdot 52 \%)$, iso- $\mathrm{C}_{15: 1}(9 \cdot 29 \%)$, iso- $\mathrm{C}_{16: 0}(8 \cdot 03 \%)$, anteiso- $\mathrm{C}_{17: 0}$

Table 1. Differential characteristics between strain YIM $70178^{\top}$ and Yania halotolerans YIM $70085^{\top}$

The following characteristics are the same for both strains: Gram-positive, non-motile cocci. The optimum $\mathrm{pH}$ for growth is $7 \cdot 0-8 \cdot 0$. Catalase-positive and oxidase-negative. Methyl red and Voges-Proskauer tests, melanin production, $\mathrm{H}_{2} \mathrm{~S}$ and indole production are negative; Tweens 20 and 80 , casein and starch are not decomposed. Positive for lysine decarboxylase, arginine dihydrolase and lipase activity. Negative for ornithine decarboxylase, L-aspartic arylamidase, $\alpha$-galactosidase activities and growth on cellulose. The following substrates are utilized as sole carbon sources for growth in both strains: maltose, glucose, mannose, fructose, salicin, acetamide and galactose, while mannitol, adonitol, arabinose, arabitol, inositol and sorbitol are not utilized. +, Positive; -, negative; DPG, diphosphatidylglycerol; PG, phosphatidylglycerol; PI, phosphatidylinositol; PL, unidentified phospholipid; GL, unidentified glycolipid.

\begin{tabular}{|c|c|c|}
\hline Characteristic & YIM $70178^{\mathrm{T}}$ & YIM $70085^{\mathrm{T}}$ \\
\hline Optimal concentration of $\mathrm{KCl}$ for growth $(\% \mathrm{w} / \mathrm{v})$ & $10-15$ & 10 \\
\hline \multicolumn{3}{|l|}{ Range of salt concentrations for growth $(\% \mathrm{w} / \mathrm{v})$} \\
\hline $\mathrm{NaCl}$ & $0 \cdot 5-25$ & $0-25$ \\
\hline $\mathrm{KCl}$ & $0 \cdot 5-30$ & $0-20$ \\
\hline $\mathrm{MgCl}_{2} \cdot 6 \mathrm{H}_{2} \mathrm{O}$ & $0 \cdot 5-30$ & $0-15$ \\
\hline $\mathrm{pH}$ range for growth & $6 \cdot 0-9 \cdot 0$ & $6 \cdot 5-8 \cdot 5$ \\
\hline Utilization of sucrose & - & + \\
\hline \multicolumn{3}{|l|}{ Enzyme activities } \\
\hline Urease & - & + \\
\hline$\beta$-Glucosidase & - & + \\
\hline$N$-Acetyl-glucosaminidase & + & - \\
\hline$\beta$-Galactosidase & + & - \\
\hline$\alpha$-Maltosidase & - & + \\
\hline Major menaquinones & MK-8 and MK-9 & MK-8 \\
\hline Polar lipids & DPG, PG, PL and GL & DPG, PG, PI, PL and GL \\
\hline Major fatty acids $(>10 \%)$ & anteiso- $\mathrm{C}_{15: 0}$ & anteiso- $\mathrm{C}_{15: 0}$, iso- $\mathrm{C}_{15: 0}$ \\
\hline $\mathrm{G}+\mathrm{C}$ content $(\mathrm{mol} \%)$ & $57 \cdot 9$ & $53 \cdot 5$ \\
\hline
\end{tabular}


Table 2. Differential chemotaxonomic characteristics of genera of the families Yaniaceae and Micrococcaceae

Data for reference taxa were taken from Stackebrandt \& Schumann (2000); Reddy et al. (2000); Liu et al. (2000); Reddy et al. (2002); Fan et al. (2002); Altenburger et al. (2002); Wieser et al. (2002); Y. Li et al. (2004); Gupta et al. (2004); W.-J. Li et al. (2004a, b, 2005); Margesin et al. (2004) and this study. $\mathrm{MCA}_{\mathrm{var}}$, Variable monocarboxylic amino acid; DCA var, variable dicarboxylic amino acid; DPG, diphosphatidylglycerol; PG, phosphatidylglycerol; PI, phosphatidylinositol; PE, phosphatidylethanolamine; DMDG, dimannosyldiacylglycerol; PL, unidentified phospholipid(s); GL, unidentified glycolipid(s). Abbreviations for menaquinones exemplified by $\mathrm{MK}-8\left(\mathrm{H}_{2}\right)$, partially saturated menaquinone with one of eight isoprene units hydrogenated and MK-9, unsaturated menaquinone with nine isoprene units. All taxa contain L-Lys as diamino acid of the cell-wall peptidoglycan.

\begin{tabular}{|c|c|c|c|c|c|c|c|c|c|}
\hline \multirow[t]{2}{*}{ Characteristic } & \multirow{2}{*}{$\frac{\text { Yaniaceae }}{\text { Yania }}$} & \multicolumn{8}{|c|}{ Micrococcaceae } \\
\hline & & Micrococcus & $\begin{array}{c}\text { Arthrobacter, } \\
\text { globiformis group }\end{array}$ & $\begin{array}{c}\text { Arthrobacter, } \\
\text { nicotianae } \text { group }\end{array}$ & Citricoccus & Kocuria & Nesterenkonia & Renibacterium & Rothia \\
\hline Interpeptide bridge & Gly-L-Glu & $\begin{array}{l}\text { Peptide subunit } \\
\text { or D-Asp }\end{array}$ & $\mathrm{MCA}_{\mathrm{var}}$ & $\begin{array}{l}\text { Ala-Glu, Ser-Glu, } \\
\text { Asp or Glu }\end{array}$ & Gly-Glu & $\mathrm{L}-\mathrm{Ala}_{3-4}$ & $\begin{array}{l}\text { Gly-L-Glu or L-Glu } \\
\text { or Gly-Asp }\end{array}$ & L-Ala-Gly & $\begin{array}{l}\text { L-Ala } \\
\text {, L-Ala, L-Ser, } \\
\text { Gly or Gly-Ala }\end{array}$ \\
\hline $\begin{array}{l}\text { Predominant } \\
\text { menaquinone(s) }\end{array}$ & MK-8, -9 & MK-8, $-8\left(\mathrm{H}_{2}\right)$ & MK-9(H $\left.\mathrm{H}_{2}\right),-8\left(\mathrm{H}_{2}\right)$ & MK-8, $-9,-10$ & $\operatorname{MK}-9\left(\mathrm{H}_{2}\right)$ & $\mathrm{MK}-7\left(\mathrm{H}_{2}\right),-8\left(\mathrm{H}_{2}\right)$ & MK-8, -9, -7 & MK-9, -10 & MK-7, $-6\left(\mathrm{H}_{2}\right)$ \\
\hline Polar lipids & $\begin{array}{l}\text { DPG, PG, } \\
\text { PL, GL }\end{array}$ & $\begin{array}{l}\text { DPG, PI, } \\
\text { PG, PL, GL }\end{array}$ & $\begin{array}{l}\text { DPG, PI, PG, } \\
\text { DMDG, PE }\end{array}$ & $\begin{array}{l}\text { DPG, PI, PG, } \\
\text { DMDG }\end{array}$ & $\begin{array}{l}\text { DPG, PG, PI, } \\
\text { GL, PL }\end{array}$ & $\begin{array}{l}\text { DPG, PG, } \\
\text { PI, PL, GL }\end{array}$ & $\begin{array}{l}\text { DPG, PI, PG, } \\
\text { PL, GL }\end{array}$ & DPG, GL & DPG, PG \\
\hline Major fatty acids & $\begin{array}{l}\text { anteiso- } \mathrm{C}_{15: 0} \\
\text { iso- } \mathrm{C}_{15: 0} \text {, or } \\
\text { anteiso- } \mathrm{C}_{15: 0}\end{array}$ & $\begin{array}{l}\text { anteiso- } \mathrm{C}_{15: 0} \\
\text { iso- } \mathrm{C}_{15: 0}\end{array}$ & $\begin{array}{l}\text { anteiso- } \mathrm{C}_{15: 0} \\
\text { iso- } \mathrm{C}_{15: 0} \\
\text { iso- } \mathrm{C}_{16: 0} \\
\text { anteiso- } \mathrm{C}_{17: 0}\end{array}$ & anteiso- $\mathrm{C}_{15: 0}$ & $\begin{array}{l}\text { anteiso- } \mathrm{C}_{15: 0} \\
\text { anteiso- } \mathrm{C}_{17: 0} \\
\text { iso- } \mathrm{C}_{15: 0}\end{array}$ & $\begin{array}{l}\text { anteiso- } \mathrm{C}_{15: 0} \\
\text { anteiso- } \mathrm{C}_{17: 0} \\
\text { iso- } \mathrm{C}_{16: 0} \\
\text { anteiso- } \mathrm{C}_{17: 1}\end{array}$ & $\begin{array}{l}\text { anteiso- } \mathrm{C}_{15: 0} \\
\text { anteiso- } \mathrm{C}_{17: 0} \\
\text { iso- } \mathrm{C}_{16: 0}\end{array}$ & $\begin{array}{l}\text { anteiso- } C_{15: 0} \\
\text { anteiso- } C_{17: 0}\end{array}$ & $\begin{array}{l}\text { anteiso- } \mathrm{C}_{15: 0} \\
\text { anteiso- } \mathrm{C}_{17: 0} \\
\mathrm{C}_{16: 0}\end{array}$ \\
\hline $\begin{array}{l}\mathrm{G}+\mathrm{C} \text { content } \\
(\mathrm{mol} \%)\end{array}$ & $53-58$ & $66-76$ & $61-69$ & $58-69$ & $64-68$ & $60-75$ & $64-72$ & $52-54$ & $49-58$ \\
\hline
\end{tabular}




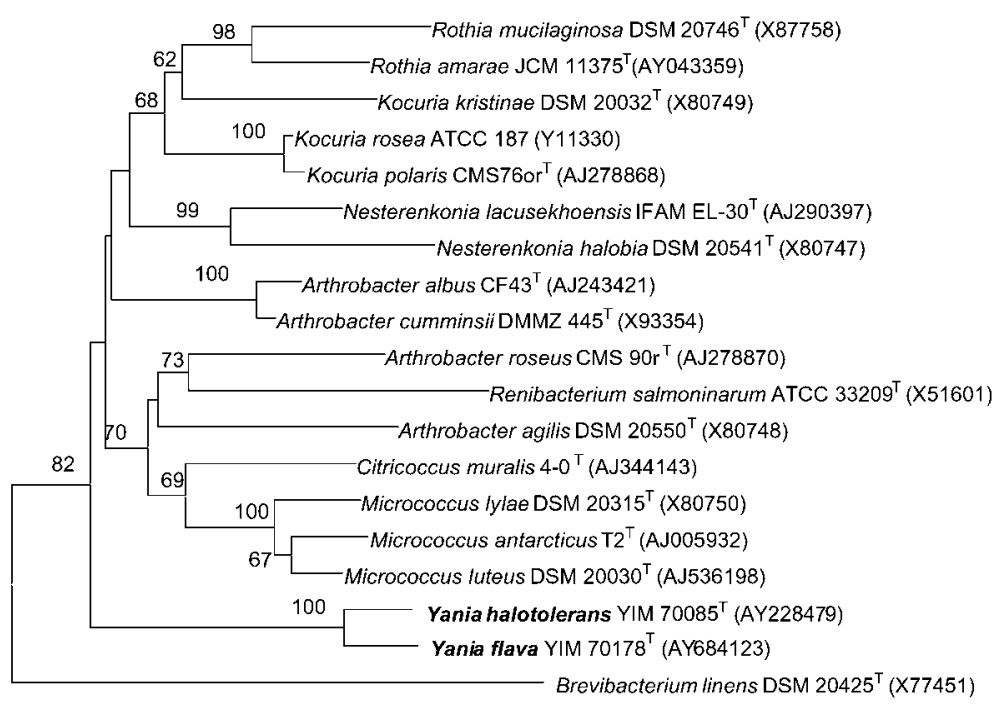

$\stackrel{0.01}{\longleftarrow}$
Fig. 1. Phylogenetic dendrogram obtained by distance matrix analysis of $16 \mathrm{~S}$ rRNA gene sequences, showing the position of strain YIM $70178^{\top}$ among phylogenetic neighbours. The sequence of Streptomyces megasporus DSM 41476 ${ }^{\top}$ (Z68100) was used as the outgroup (not shown). Numbers on branch nodes are bootstrap percentages (1000 resamplings, only values over $50 \%$ are given). Bar, $1 \%$ sequence divergence.
$(5 \cdot 79 \%)$, iso- $\mathrm{C}_{13: 0}(2 \cdot 08 \%)$, iso- $\mathrm{C}_{17: 0} \quad(1 \cdot 88 \%), \mathrm{C}_{16: 0}$ $(0.59 \%)$, anteiso- $\mathrm{C}_{15: 1}(0.51 \%)$, anteiso- $\mathrm{C}_{13: 0}(0.38 \%)$, $\mathrm{C}_{16: 1} \omega 7 c(0 \cdot 35 \%), \mathrm{C}_{18: 1} \omega 9 c(0 \cdot 25 \%)$ and $\mathrm{C}_{14: 0}(0 \cdot 13 \%)$. Additional chemotaxonomic data are shown in Tables 1 and 2.

Extraction of genomic DNA and amplification of the 16S rRNA gene were performed according to Xu et al. (2003). Phylogenetic analysis was conducted using the MEGA version 2.1 software package (Kumar et al., 2001) after multiple alignment of data by CLUSTAL_X (Thompson et al., 1997). Distances (distance options according to the Kimura twoparameter model) (Kimura, 1980, 1983) and clustering were performed using the neighbour-joining (Saitou \& Nei, 1987) and maximum-likelihood (Felsenstein, 1981) methods. Bootstrap analysis was used to evaluate the tree topology of the neighbour-joining data by performing 1000 resamplings (Felsenstein, 1985).

The almost-complete 16S rRNA gene sequence of strain YIM $70178^{\mathrm{T}}$ (1493 bp) was determined. Phylogenetic analysis, based on a dataset consisting of 1376 unambiguous nucleotides between positions 42 and 1417, showed that the novel isolate was most closely related to Yania halotolerans YIM $70085^{\mathrm{T}}$. A dendrogram (Fig. 1) confirmed that strains YIM $70178^{\mathrm{T}}$ and YIM $70085^{\mathrm{T}}$ are phylogenetic neighbours with $98.4 \% 16 \mathrm{~S}$ rRNA gene sequence similarity and a bootstrap value of $100 \%$. Similarity values with sequences of neighbouring taxa were significantly lower $(89 \cdot 2-94 \cdot 0 \%)$. A detailed phylogenetic tree displaying the phylogenetic position of strain YIM $70178^{\mathrm{T}}$, Yania halotolerans YIM $70085^{\mathrm{T}}$ and related taxa in the suborder Micrococcineae is available as Supplementary Fig. S1 in IJSEM Online.

The isolate YIM $70178^{\mathrm{T}}$ was different from Yania halotolerans YIM $70085^{\mathrm{T}}$ in some physiological, biochemical and chemotaxonomic characteristics (Table 1). DNA-DNA relatedness tests were performed between strain YIM $70178^{\mathrm{T}}$ and Yania halotolerans YIM $70085^{\mathrm{T}}$ using the optical renaturation method (De Ley et al., 1970; Huß et al., 1983; Jahnke, 1992) and DNA-DNA relatedness between the strains was $35 \cdot 4 \%$. DNA-DNA relatedness provided decisive evidence that strain YIM $70178^{\mathrm{T}}$ and Yania halotolerans YIM $70085^{\mathrm{T}}$ are members of different genomic species (Wayne et al., 1987). Therefore, based on the above phenotypic and genotypic results, we consider strain YIM $70178^{\mathrm{T}}$ to represent a novel species of the genus Yania, for which we propose the name Yania flava sp. nov.

The results of 16S rRNA gene sequence comparisons clearly demonstrated that strains YIM $70178^{\mathrm{T}}$ and YIM $70085^{\mathrm{T}}$ are members of the suborder Micrococcineae. Both strains have some unique 16S rRNA gene signature nucleotides compared with other families of the suborder Micrococcineae, such as 140-223 (A-G), 142-221 (C-A), 615-625 (G-U), 839-847 (A-A) and 1134-1140 (A-U) (this study and W.-J. Li et al., 2004a). Strain YIM $70178^{\mathrm{T}}$ was isolated from Qinghai Province, north-west China and strain YIM $70085^{\mathrm{T}}$ originated from Xinjiang Province, in the north of China. Since the two strains were isolated from independent and geographically distant sources, they provide a first estimation of the phenotypic diversity of the genus Yania. As discussed previously (W.-J. Li et al., 2004a), the unique set of 16S rRNA gene signature nucleotides and chemotaxonomic markers distinguish the genus Yania from members of the closest family Micrococcaceae in the suborder Micrococcineae (Table 2). Thus, the family Yaniaceae fam. nov. is proposed.

\section{Description of Yaniaceae fam. nov.}

Yaniaceae (Ya'ni.a'ce.ae. N.L. fem. n. Yania type genus of the family; -aceae ending to denote a family; N.L. fem. pl. n. Yaniaceae the Yania family).

The pattern of $16 \mathrm{~S}$ rRNA gene sequence signatures consists of nucleotides at positions 140-223 (A-G), 142-221 (C-A), 
615-625 (G-U), 839-847 (A-A) and 1134-1140 (A-U) (W.-J. Li et al., 2004a). The type genus is Yania.

\section{Emended description of the genus Yania Li et al. 2004}

The description of the genus Yania (W.-J. Li et al., 2004) is emended as follows. Moderately halophilic or halotolerant. The polar lipids contain diphosphatidylglycerol, phosphatidylglycerol, an unknown phospholipid and an unknown glycolipid. The predominant menaquinone(s) are MK-8 and MK-9 or MK-8. The major cellular fatty acids are anteiso- $\mathrm{C}_{15: 0}$ and iso- $\mathrm{C}_{15: 0}$ or anteiso- $\mathrm{C}_{15: 0}$. The DNA $\mathrm{G}+\mathrm{C}$ content is $53-58 \mathrm{~mol} \%$.

\section{Description of Yania flava sp. nov.}

Yania flava (fla'va. L. fem. adj. flava golden yellow, referring to the colour of the colonies).

Morphological, chemotaxonomic and general characteristics are as described for the genus. Colonies are light yellow, circular, lubricous and opaque. Acid is produced from glucose, maltose and fructose. It is negative for milk peptonization, milk coagulation, urease and nitrate reduction, gelatin liquefaction, growth in cellulose, $\mathrm{H}_{2} \mathrm{~S}$ and melanin production. Some other physiological and biochemical characteristics are listed in Table 1. The cell-wall peptidoglycan type is A4 $\alpha$, L-Lys-Gly-L-Glu. The polar lipids contain diphosphatidylglycerol, phosphatidylglycerol, an unknown phospholipid and an unknown glycolipid. The predominant menaquinones are MK-8 and MK-9. The major cellular fatty acid is anteiso- $\mathrm{C}_{15: 0}$. The DNA G+C content is $57.9 \mathrm{~mol} \%$ (HPLC method).

The type strain, YIM $70178^{\mathrm{T}}\left(=\mathrm{DSM} 16377^{\mathrm{T}}=\mathrm{KCTC}\right.$ $19047^{\mathrm{T}}$ ), was isolated from a saline soil collected from Qinghai Province, north-west China.

\section{Acknowledgements}

This research was supported by National Basic Research Program of China (project no. 2004CB719601), National Natural Science Foundation of China (project no. 30270004) and Yunnan Provincial Natural Science Foundation (project no. 2004C0002Q).

\section{References}

Al-Tai, A. M. \& Ruan, J. S. (1994). Nocardiopsis halophila sp. nov., a new halophilic actinomycete isolated from soil. Int J Syst Bacteriol 44, 474-478.

Altenburger, P., Kämpfer, P., Schumann, P., Steiner, R., Lubitz, W. \& Busse, H. J. (2002). Citricoccus muralis gen. nov., sp. nov., a novel actinobacterium isolated from a medieval wall painting. Int $J$ Syst Evol Microbiol 52, 2095-2100.

Chen, H.-H., Li, W.-J., Tang, S.-K., Kroppenstedt, R. M., Stackebrandt, E., Xu, L.-H. \& Jiang, C.-L. (2004). Corynebacterium halotolerans sp. nov., isolated from saline soil in the west of China. Int J Syst Evol Microbiol 54, 779-782.
De Ley, J., Cattoir, H. \& Reynaerts, A. (1970). The quantitative measurement of DNA hybridization from renaturation rates. Eur J Biochem 12, 133-142.

Fan, Y., Jin, Z., Tong, J., Li, W., Pasciak, M., Gamian, A., Liu, Z. \& Huang, Y. (2002). Rothia amarae sp. nov., from sludge of a foul water sewer. Int J Syst Evol Microbiol 52, 2257-2260.

Felsenstein, J. (1981). Evolutionary trees from DNA sequences: a maximum likelihood approach. J Mol Evol 17, 368-376.

Felsenstein, J. (1985). Confidence limits on phylogenies: an approach using the bootstrap. Evolution 39, 783-791.

Garrity, G. M. \& Holt, J. G. (2001). Taxonomic outline of the Archaea and Bacteria. In Bergey's Manual of Systematic Bacteriology, 2nd edn, vol. 1. The Archaea and the Deeply Branching and Phototrophic Bacteria, pp. 155-166. Edited by D. R. Boone \& R. W. Castenholz. New York: Springer-Verlag.

Gordon, R. E., Barnett, D. A., Handerhan, J. E. \& Pang, C. H.-N. (1974). Nocardia coeliaca, Nocardia autotrophica, and the nocardin strain. Int J Syst Bacteriol 24, 54-63.

Gupta, P., Reddy, G. S. N., Delille, D. \& Shivaji, S. (2004). Arthrobacter gangotriensis sp. nov. and Arthrobacter kerguelensis sp. nov. from Antarctica. Int J Syst Evol Microbiol 54, 2375-2378.

Huß, V. A. R., Festl, H. \& Schleifer, K. H. (1983). Studies on the spectrophotometric determination of DNA hybridization from renaturation rates. Syst Appl Microbiol 4, 184-192.

Jahnke, K. D. (1992). BASIC computer program for evaluation of spectroscopic DNA renaturation data from Gilford System 2600 spectrophotometer on a PC/XT/AT type personal computer. J Microbiol Methods 15, 61-73.

Kelly, K. L. (1964). Inter-Society Color Council - National Bureau of Standards Color-Name Charts Illustrated with Centroid Colors. Washington, DC: US Government Printing Office.

Kimura, M. (1980). A simple method for estimating evolutionary rates of base substitutions through comparative studies of nucleotide sequences. J Mol Evol 16, 111-120.

Kimura, M. (1983). The Neutral Theory of Molecular Evolution. Cambridge: Cambridge University Press.

Kumar, S., Tamura, K., Jakobsen, I. B. \& Nei, M. (2001). MEGA2: molecular evolutionary genetics analysis software. Bioinformatics 17, 1244-1245.

Li, W.-J., Chen, H.-H., Xu, P., Zhang, Y.-Q., Schumann, P., Tang, S.-K., Xu, L.-H. \& Jiang, C.-L. (2004a). Yania halotolerans gen. nov., sp. nov., a novel member of the suborder Micrococcineae from saline soil in China. Int J Syst Evol Microbiol 54, 525-531.

Li, W.-J., Chen, H.-H., Zhang, Y.-Q., Schumann, P., Stackebrandt, E., $\mathbf{X u}$, L.-H. \& Jiang, C.-L. (2004b). Nesterenkonia halotolerans sp. nov. and Nesterenkonia xinjiangensis sp. nov., actinobacteria from saline soils in the west of China. Int J Syst Evol Microbiol 54, 837-841.

Li, Y., Kawamura, Y., Fujiwara, N., Naka, T., Liu, H., Huang, X., Kobayashi, K. \& Ezaki, T. (2004). Rothia aeria sp. nov., Rhodococcus baikonurensis sp. nov. and Arthrobacter russicus sp. nov., isolated from air in the Russian space laboratory Mir. Int J Syst Evol Microbiol 54, 827-835.

Li, W.-J., Chen, H.-H., Kim, C.-J., Zhang, Y.-Q., Park, D.-J., Lee, J.-C., Xu, L.-H. \& Jiang, C.-L. (2005). Nesterenkonia sandarakina sp. nov. and Nesterenkonia lutea sp. nov., novel actinobacteria, and emended description of the genus Nesterenkonia. Int J Syst Evol Microbiol 55, 463-466.

Liu, H., Xu, Y., Ma, Y. \& Zhou, P. (2000). Characterization of Micrococcus antarcticus sp. nov., a psychrophilic bacterium from Antarctica. Int J Syst Evol Microbiol 50, 715-719. 
Margesin, R., Schumann, P., Spröer, C. \& Gounot, A. M. (2004). Arthrobacter psychrophenolicus sp. nov., isolated from an alpine ice cave. Int J Syst Evol Microbiol 54, 2067-2072.

Mesbah, M., Premachandran, U. \& Whitman, W. B. (1989). Precise measurement of the $\mathrm{G}+\mathrm{C}$ content of deoxyribonucleic acid by highperformance liquid chromatography. Int J Syst Bacteriol 39, 159-167.

Reddy, G. S. N., Aggarwal, R. K., Matsumoto, G. I. \& Shivaji, S. (2000). Arthrobacter flavus sp. nov., a psychrophilic bacterium isolated from a pond in McMurdo Dry Valley, Antarctica. Int J Syst Evol Microbiol 50, 1553-1561.

Reddy, G. S. N., Prakash, J. S. S., Matsumoto, G. I., Stackebrandt, E. \& Shivaji, S. (2002). Arthrobacter roseus sp. nov., a psychrophilic bacterium isolated from an Antarctic cyanobacterial mat sample. Int J Syst Evol Microbiol 52, 1017-1021.

Saitou, N. \& Nei, M. (1987). The neighbor-joining method: a new method for reconstructing phylogenetic trees. Mol Biol Evol 4, 406-425.

Stackebrandt, E. \& Schumann, P. (2000). Description of Bogoriellaceae fam. nov., Dermacoccaceae fam. nov., Rarobacteraceae fam. nov. and Sanguibacteraceae fam. nov. and emendation of some families of the suborder Micrococcineae. Int I Syst Evol Microbiol 50, 1279-1285.

Stackebrandt, E., Rainey, F. A. \& Ward-Rainey, N. L. (1997). Proposal for a new hierarchic classification system, Actinobacteria classis nov. Int J Syst Bacteriol 47, 479-491.

Thompson, J. D., Gibson, T. J., Plewniak, F., Jeanmougin, F. \& Higgins, D. G. (1997). The CLUSTAL_X windows interface: flexible strategies for multiple sequence alignment aided by quality analysis tools. Nucleic Acids Res 24, 4876-4882.

Wayne, L. G., Brenner, D. J., Colwell, R. R. \& 9 other authors (1987). International Committee on Systematic Bacteriology. Report of the ad hoc committee on reconciliation of approaches to bacterial systematics. Int J Syst Bacteriol 37, 463-464.

Wieser, M., Denner, E. B. M., Kämpfer, P. \& 10 other authors (2002). Emended descriptions of the genus Micrococcus, Micrococcus luteus (Cohn 1872) and Micrococcus lylae (Kloos et al. 1974). Int J Syst Evol Microbiol 52, 629-637.

Xu, P., Li, W.-J., Xu, L.-H. \& Jiang, C.-L. (2003). A microwave-based method for genomic DNA extraction from Actinomycetes. Microbiology 30, 73-75 (in Chinese). 